\author{
MAŁGORZATA DAJNOWICZ \\ Instytut Historii i Nauk Politycznych \\ Uniwersytet w Białymstoku \\ e-mail:malgorzatadajnowicz@gmail.com
}

\title{
WIZERUNEK KOBIET SFERY POLITYKI. POLSKA NA TLE PAŃSTW ZACHODNICH (NA PODSTAWIE ANALIZY TREŚCI WYBRANYCH TYGODNIKÓW)
}

\section{Uwagi wstępne}

Tematyka dotycząca badań wizerunku politycznego kobiet zaangażowanych w sferę polityki pozostaje jak dotąd dość słabo prezentowana w publikacjach naukowych. Podejmowano tę problematykę głównie w kontekście badań nad komunikacją polityczną czy znaczeniem mediów w odniesieniu do komunikacji politycznej. W polskim dyskursie naukowym dosyć dobrze opracowana pozostaje tematyka traktująca o szeroko rozumianym wizerunku, komunikacji (w tym wizualnej) czy public relations, odnosząca się do badań nad sferą publiczną czy medialną ${ }^{1}$.

Media masowe, $w$ tym prasa były przedmiotem badań empirycznych, prowadzonych zwłaszcza przez socjologów i politologów. Studia nad znaczeniem mediów w komunikacji politycznej zapoczątkowali badacze zachodni, przodowali w tej mierze już w pierwszej połowie XX w. badacze amerykańscy, następnie zachodnioeuropejscy (niemieccy, szwedzcy czy holenderscy). Ilościowa i jako-

$1 \quad$ Zob. przykładowe najnowsze opracowania : Public Relations w sferze publicznej. Wizerunek i komunikacja, red. M. Tabernacka, A. Szadok-Bratuń, Warszawa 2012; Komunikacja wizualna w reklamie, public relations $i$ w prawie, red. K. Wolny-Zmorzyński, W. Furman, J. Snopek, K. Groń, Warszawa 2013. 
ściowa analiza zawartości przekazów medialnych o polityce prowadzona jest od lat siedemdziesiątych XX w. Zwłaszcza wiele miejsca w analizach badawczych poświęcono scenie politycznej, w tym ,,aktorom politycznym” okresu kampanii wyborczych ${ }^{2}$.

$\mathrm{Na}$ oddzielne potraktowanie zasługuje kwestia dotycząca analizy wizerunku polityków oraz wizerunku osób będących w orbicie zainteresowania sfery polityki, eksponowanych w przekazach medialnych, w tym w prasie ${ }^{3}$. Najczęściej $\mathrm{w}$ analizie wizerunku zwraca się uwagę na jego wymiar socjologiczny, marketingowy i komunikacyjny ${ }^{4}$. W opisie i definiowaniu wizerunku wskazuje się głównie na zespół elementów składających się na postrzeganie danej osoby, dotyczących informacji o niej, formułowanych ocen, wyobrażeń, poglądów na temat jej działalności, czy zachowań ${ }^{5}$. W definiowaniu wizerunku kładzie się akcenty zwłaszcza na wyobrażenie, najczęściej przesadne, subiektywne i wartościujące na temat czegoś lub kogoś. Współczesna dyskusja naukowa nad znaczeniem wizerunku w przestrzeni publicznej zapoczątkowana została przez zachodnich badaczy. Definicję wizerunku rozważał amerykanin Walter Lippmann w pracy Public Opinion, opublikowanej w 1925 r., w której to łączył kształtowanie opinii publicznej z wyobrażeniami odbiorcy przekazu publicznego ${ }^{6}$.

W przygotowaniu treści artykułu zostanie wykorzystana klasyczna metoda badawcza stosowana przez medioznawców, jaką jest metoda analizy zawartości prasy (analiza zawartości treści tekstów traktujących o kobietach jako uczestniczkach przestrzeni politycznej) ${ }^{7}$. Biorąc pod uwagę teksty tygodników uwzględniono także metody stosowane $\mathrm{w}$ badaniach nad zawartością komunikatów o polityce, a więc metodę ilościową (przeanalizowano teksty, w których wystąpiła problematyka udziału kobiet w polityce oraz dotycząca wizerunku tych kobiet) oraz jakościową (ocena materiału pod względem ,,przydatności” dla przedstawienia zagadnienia wizerunku kobiet). Analizie poddano artykuły tygodników z czasu kampanii wyborczej do Parlamentu Europejskiego w latach 2004 i 2014. Były to czasy, w których w większej mierze, w porównaniu do okresów „,mię-

2 Cyt. za B. Dobek-Ostrowską, Studia empiryczne nad komunikowaniem politycznym, [w:] Studia empiryczne nad komunikowaniem politycznym w Polsce, red. B. Dobek-Ostrowska, Wrocław 2011, s. 13-29.

3 T. Gackowski, M. Łączyński, Analiza wizerunku w mediach, Warszawa 2008.

4 Tamże, s. 83.

5 Zob. G. Białopiotrowicz, Kreowanie wizerunku w biznesie i polityce, Warszawa 2009, s. 17 i n.

6 K. Giereło, Wizerunek (image) polityka - teoria i praktyka, [w:] Public relations $w$ teorii i praktyce, red. B. Ociepka, Wrocław 2003, s. 22 i n.

7 J. Pisarek, Analiza zawartości prasy, Kraków 1983. 
dzywyborczych", występowała tematyka dotycząca w ogóle sfery polityki i prezentowania kandydatów na europosłów. Pod względem chronologicznym wybór 2004 i 2014 r. pozwolił na porównanie miejsca kobiet w przestrzeni politycznej w odniesieniu do tych lat oraz przede wszystkim wyłonienie różnic w postrzeganiu kobiet jako uczestniczek polityki (ich wizerunku) oraz różnic dotyczących eksponowania tematyki na łamach tych czasopism - w 2004 i po dziesięciu latach - w $2014 \mathrm{r}$.

Pod względem doboru materiału do analizy ujęto wszystkie teksty, które $\mathrm{w}$ większej lub mniejszej mierze traktowały na temat zagadnienia udziału kobiet $\mathrm{w}$ polityce. $\mathrm{Z}$ jednej strony prezentowany materiał pozostaje niekwestionowanym źródłem wiedzy o ówczesnej scenie politycznej i miejscu w niej kobiet, z drugiej zaś jest pewnego rodzaju subiektywną prezentacją przekazu medialnego na temat kobiet w polityce. Część analizowanych treści dotyczyła wytworu wspólnego „aktorów politycznych” (kobiet uczestniczek życia politycznego) i mediów (artykuły w postaci wywiadów), część artykułów będących gatunkiem przekazu politycznego i udziału w nim kobiet ${ }^{8}$. Analizie poddano opracowania publicystyczne, wywiady i komunikaty i inne przekazy pisane, pomijając odniesienia do obrazów graficznych (fotografii kobiet).

Do niniejszego opracowania wykorzystano najbardziej opiniotwórcze polskie tygodniki „Politykę”, „Wprost” i „Newsweek Polska”. Przeanalizowano łącznie 66 numerów z 2004 r. oraz 78 numerów z 2014 r. (po 22 w 2004 i 26 z 2014 z każdego tygodnika), wykorzystując artykuły, w których poruszano zagadnienie udziału kobiet $\mathrm{w}$ polityce ${ }^{9}$. Już na poziome ekscerpcji materiału prasowego, dotyczącego analizowanego zagadnienia, należy wskazać na bardzo wyraźnie różnice pomiędzy treścią tygodników w 2004 i 2014 r. W 2004 r. na łamach wymienionych gazet tematyka uczestnictwa politycznego kobiet podejmowana była w zasadzie sporadycznie. Spośród prezentowanych tygodników w największym stopniu poruszono tę problematykę w "Polityce” i w „Newsweek Polska” (w prawie 10\% gazet) i w zasadzie w ogóle tematyka

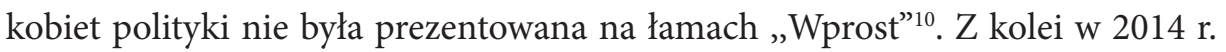

8 Zob. B. Dobek-Ostrowska, Studia empiryczne..., s. 16-17.

9 W odniesieniu do 2004 r. przeanalizowano tygodniki od początku roku do końca maja, pierwsze numery analizowanych gazet z 2014 r. odnosiły się do początku roku, ostatnie do przełomu czerwca i lipca $2014 \mathrm{r}$.

10 Był to jeden komunikat dotyczący polskich polityków, w którym znalazły się krótkie jednozdaniowe odniesienia do Aleksandry Jakubowskiej (Sojusz Lewicy Demokratycznej) i Aldony Kameli Sowińskiej (Inicjatywa dla Polski). Niniejszy tekst nie wniósł informacji do zagadnienia wizerunku kobiet, w związku z tym w artykule pominięto odniesienia do niniejszej publikacji - Z życia koalicji, „Wprost” (dalej: „W”) 2004, 21 marca, s. 14-15. 
problematyka odnosząca się do kobiet polityki wystąpiła w ponad 35\% wydań tygodników.

\section{Kobiety polityki w państwach zachodnich}

W 2004 tematyka kobiet polityki w odniesieniu do państw Zachodu wystąpiła w bardzo wąskim zakresie. W zasadzie jedynie w tygodniku „Polityka” pojawił się komunikat odnoszący się do „wpływowej doradczyni Prezydenta” Georga W. Busha do spraw bezpieczeństwa narodowego Condoleezzy Rice. Komunikat dotyczył kwestii przesłuchań członków gabinetu Prezydenta w odniesieniu do okoliczności zamachu terrorystycznego z 11 września 2011 r. Condoleezza Rice przedstawiona została jako osoba stanowcza i kompetentna, jednocześnie uznająca kompromisy dla celu nadrzędnego, jakim pozostawała dbałość o pozytywny wizerunek gabinetu Prezydenta USA ${ }^{11}$.

Problematyka kobiet polityki USA, związanych z Prezydentem Stanów Zjednoczonych Ameryki wystąpiła w znacznie większym wymiarze w tygodnikach z 2014 r. W artykułach prasowych eksponowano zwłaszcza sylwetkę amerykańskiej, światowej polityki Hilary Clinton. We wszystkich opisach dotyczących Hilary Clinton dominowało wskazanie cech dotyczących jej wizerunku jako kobiety „ambitnej, dzielnej, bojowej, nieskruszonej, nieustępliwej, bezpośredniej, pragmatycznej”. Te cechy miały stanowić o jej skuteczności politycznej i umożliwiać dążenia do sukcesu w postaci wyniku wyborczego, zapewniającego fotel prezydencki w 2016 r. Życiorys polityczny został ukazany na tle jej trudnej drogi do polityki, a także kariery politycznej Prezydenta Billa Clintona. W opisach dominująca była problematyka związana z wyeksponowaniem trudności, jakie pokonywała Clinton w walce o fotel Prezydenta Stanów Zjednoczonych. W artykułach zostały opisane także podejmowane przez nią próby ocieplania wizerunku, przez eksponowanie w jej poglądach tradycyjnego stosunku do wartości rodzinnych, ukazywanie działalności charytatywnej czy szerokich zainteresowań pozapolitycznych. O silnej pozycji politycznej Hillary Clinton i jej realnej szansie w wyborach prezydenckich w 2016 r. - co wskazano we wszystkich publikacjach prasowych na jej temat - decydowało również zaangażowanie w sprawy polityki całej rodziny Clintonów (Billa, córki Chelsey) oraz według niektórych prognoz politycznych - zasadniczy wpływ na jej polityczny sukces odgrywała „słabość”

11 Condie będzie zeznawać, „Polityka” (dalej „P”) 2004, nr 15, 10 kwietnia, s. 16. 
prezydentury Obamy, który „niespodziewanie wcześnie wszedł w okres, który Amerykanie nazywają lame duck (kulawa kaczka) - formalnie jest u władzy, ale praktycznie nie rządzi i wyczekuje końca kadencji. (...) Obama wydaje się gotowy, by oddać wodze, a Clintonowie już dziś z ochotą je przyjmują" - komentował „New York Times”'2.

Zupełnie odmienny od Hillary Clinton kreowany był wizerunek Michelle Obamy, pozostającej „najbardziej hołubioną przez media pierwszą damą od czasu Jacqueline Kennedy". Mimo że nie funkcjonuje w polityce w takim wymiarze jak Hillary Clinton za prezydentury Billa Clintona, według ocen doradców Obamy ma równie poważny wpływ, jak jej poprzedniczka, na decyzje polityczne Prezydenta. Sukces wizerunkowy w mediach zawdzięcza m.in. przyjęciu i eksponowaniu zasady promowania wartości rodzinnych, w pełni akceptowanej przez większość Amerykanów. Za taki obraz jej wizerunku i postawę Pierwszej Damy krytycznej ocenie poddały ją niektóre środowiska, m.in. feministyczne i lewicowe. Zdaniem działaczek feministycznych, Michelle Obama nie wykorzystywała, co powinna robić, pozycji i popularności na rzecz środowisk kobiecych, bronić pokrzywdzonych, w tym właśnie kobiet. W wywiadzie dla „Vogua” Michelle Obama oświadczyła, że najważniejsza jest rodzina, co bardzo istotne, z taką deklaracją właśnie identyfikuje się bardzo znacząca, jeśli nie większa część Amerykanów. „Pod każdym względem stanowi uosobienie nowoczesnej, amerykańskiej kobiety sukcesu - pisał „New York Times» - Melanż holywoodzkiego splendoru i kapryśnego indywidualizmu, dyptyk zjawiskowej belle femme [pięknej kobiety] i troskliwej mamy, która nie opuszcza żadnej wywiadówki”. $\mathrm{Z}$ pewnością wpływ na pozytywną ocenę Amerykanów na temat Michelle Obamy ma również fakt, że pochodzi $\mathrm{z}$ niezamożnej amerykańskiej rodziny o tradycyjnych wartościach, oraz mimo ograniczeń, także związanych z dyskryminacją rasową, Pierwsza Dama skończyła socjologię, następnie Wydział Prawa Harvardu i pracowała w prestiżowej kancelarii prawniczej. Ponadto większość Amerykanów jest przekonana, że Michelle Obama jest dumna i szczęśliwa z powodu faktu, że mężczyzna jej życia został przywódcą tzw. wolnego świata ${ }^{13}$.

Mimo przywoływanych na łamach analizowanej prasy przykładów sukcesów kobiet amerykańskich w zakresie ich karier politycznych, specjaliści od wizerunku kobiet polityki wskazują na bariery i ograniczenia, które dotyczą starających

12 M. [Maciej] Jarkowiec Clintonowie rządza. Dynastia, „W” 2014, nr 22, 26 maja, s. 78-80; tenże, Grzanie Hillary, „W” 2014, nr 8, 17 lutego, s. 84-86; P. [Piotr] Milewski, Szanse Hillary Clinton. Prezydentka, „Newsweek Polska” (dalej: „NP”) 2014, nr 12, 17 marca, s. 59-61.

13 Tenże, Pół wieku Michelle Obamy, „NP” 2014, nr 5, 27 stycznia, s. 58-61. 
się o stanowiska polityczne Amerykanek. Badania wskazują, że Amerykanki niechętnie głosują na kobiety, o czym przekonała się Hillary Clinton podczas wyborów w 2008 r., kiedy to właśnie głosami kobiet w części stanów USA przegrała prawybory z Barackiem Obamą. Specjaliści od marketingu politycznego, analizujący kampanie wyborcze wskazują, że kobiety stawiają przed kandydatkami większe wymagania niż przed kandydatami. Często zadają pytania typu: „A kto zajmie się dziećmi? Jakim cudem ona daje radę startować w jakiś wyborach, kiedy ja nie mam nawet czasu skoczyć na siłownię? Mężczyźni nie muszą wysłuchiwać takich pytań, w ich przypadku poświęcenie dla kariery jest dla większości wyborców oczywiste, ponieważ Stany na tle wielu krajów Europy Zachodniej pozostają jednak krainą patriarchatu"14.

Symbolem sukcesu i osobowością nie tylko europejskiej, ale i światowej polityki pozostaje Angela Merkel, która w plebiscycie organizowanym przez tygodnik ,Wprost” uzyskała tytuł człowieka roku 2013. Polacy wskazali A. Merkel jako najważniejszego polityka zagranicznego ubiegłego roku. W wizerunku Angeli Merkel wyraźnie eksponuje się powiązanie kanclerz z silną gospodarką niemiecką i znaczeniem Niemiec w polityce globalnej, w tym skuteczną polityką kanclerz wobec kryzysu europejskiego i dalej światowego. Ponadto kanclerz Niemiec postrzegana jest w Polsce jako sojuszniczka spraw polskich w Europie, przykładowo, przychylna sprawie polskiej w kwestii unijnej dotacji w $2012 \mathrm{r}$. Na pozytywne oceny Polaków zasługuje także dzięki podkreślanym w relacjach z Polską dawnym związkom rodzinnym. W przekazie prasowym podkreślana była przede wszystkim jej bardzo silna pozycja w Niemczech (trzecią kadencję zasiada na czele rządu) i na świecie (określana jako „najpotężniejsza kobieta świata, królowa Europy, Angela wielka czy Kobieta rządząca nimi wszystkimi”). Jednocześnie Angela Merkel postrzegana jest jako ta, która dba przede wszystkim o interes niemiecki, a dobre kontakty z Polską leżą właśnie w interesie Niemiec. Ponadto, co również wpływa na pozytywną ocenę jej wizerunku, Angela Merkel dla wielu Niemców jest usposobieniem solidności i spokoju. „Choć rządzi trzecią kadencję - pisano we «Wprost» - paradoksalnie uchodzi za osobę zupełnie niezabiegającą o władzę. Rodacy wierzą, że dla ich przywódczyni liczą się tylko załatwione sprawy. Siła Merkel w znaczącym stopniu polega na strategii - jak podawał korespondent «New York Timesa» - polegającej na zwyczajności i naturalności”15.

14 M. Jarkowiec, Baby z jajami, „W” 2014, nr 19, 5 maja, s. 66-68.

15 A. Burzyńska, A. Gielewska, Andela Merkelowska, „W” 2014, nr 2, 7 stycznia, s. 10-15. 
Na podstawie analizy treści tygodników można wskazać, że dominującym wizerunkiem eksponowanym przez media są postacie kobiet, które odniosły spektakularny, również międzynarodowy sukces polityczny. W tygodnikach prezentowano kobiety polityki jako osobowości charyzmatyczne, o długoletniej i wieloobszarowej aktywności politycznej, jednocześnie będące przykładem kobiet sukcesu na niwie publicznej jak i prywatnej (rodzinnej). W tygodnikach odwoływano się do przykładów kobiet z państw zachodnich o silnej pozycji globalnej, co jednocześnie wpływało na wzmocnienie znaczenia tych kobiet na arenie światowej, utożsamianie ich ze znaczeniem czy uczestnictwem tych państw w polityce ponadnarodowej.

\section{Kobiety polityki w Polsce}

Polskie kobiety polityki, to postaci znane z wcześniejszej działalności publicznej, w tym politycznej i wypowiedzi medialnych na temat polityki. Ich sylwetki oraz poglądy zostały przedstawione na łamach prasy w kontekście głównie wyborów do Parlamentu Europejskiego.

Kobietą cieszącą się zainteresowaniem mediów w 2004 r. pozostawała bez wątpienia Jolanta Kwaśniewska. Jej sylwetka prezentowana była na łamach prasy w kontekście wyborów prezydenckich. Prasa ukazywała J. Kwaśniewską jako ewentualną przyszłą kandydatkę na Prezydenta Polski. Jako profesjonalną i eksponowaną przez media, cieszącą się zainteresowaniem opinii publicznej wyłaniano działalność charytatywną J. Kwaśniewskiej „jedno z głównych źródeł popularności prezydentowej”. Ponadto, działalność charytatywna w świetle przekazu kierowanego do opinii publicznej miałaby być ,,apolityczna”, oddzielana od polityki. Na pozytywny wizerunek J. Kwaśniewskiej wpływ miało również to, że z jednej strony otaczała się środowiskami feministycznymi (kobiecymi) z drugiej zaś unikała szczegółowych wypowiedzi na tematy kontrowersyjne, takie jak stosunek do aborcji czy stanowisko wobec związków homoseksualnych. Nie bez wpływu na jej wizerunek pozostawało również, że ukazywana była w mediach bardzo często, eksponowano głównie jej obraz jako wrażliwej, inteligentnej, o nienagannym wizerunku zewnętrznym kobiety, jednocześnie, mimo dużej popularności wśród mediów, źle znoszącą krytykę mediów ${ }^{16}$. Na łamach „Polityki” w odniesieniu do Jolanty Kwaśniewskiej pisano, że to właśnie - „per-

16 M. Karnowski, Armia Pani Jolanty, „NP” 2004, nr 1, 4 stycznia, s. 16. 
fekcyjna i konsekwentna polityka pr [pablic relation - M.D.] przyniosła zasłużony efekt - ogromne społeczne poparcie. Mistrzowsko wykreowany wizerunek wielkodusznej i nietykalnej damy z wyższych sfer". Ocena jej wizerunku pojawiała się również na łamach niniejszego tygodnika w odniesieniu do jej przyszłej kariery politycznej, umiejscawianej w realiach prezydenta Polski. Pisano, że „im bliżej końca kadencji Aleksandra Kwaśniewskiego, jej deklaracje stawały się wyraźniejsze, a wypowiedzi coraz bardziej polityczne i zdecydowane". Dostrzegano w jej kreowanym wizerunku wpływ wzorców zachodnich, wskazywano wręcz, że w zachowaniach publicznych wzoruje się na Hilary Clinthon ${ }^{17}$.

Wśród opisywanych postaci pojawiła się również ocena wizerunku Zyty Gilowskiej, w którym podkreślano, że promuje wizerunek równej babki. Równej ale mądrzejszej niż inni - więc jest słuchana. Ostatnio chyba najbardziej zasłużona dla promowania liberalnych treści gospodarczych ${ }^{18}$. Na łamach „Polityki” w lutym 2004 r. ukazał się artykuł popularyzujący i zarazem wyraźnie promujący sylwetkę kandydatki do Europarlamentu Róży Thun. W tekście skupiono się na przedstawieniu jej życiorysu z wyeksponowaniem przeszłości dotyczącej jej rodziny, ze wskazaniem znanych przodków z polskich rodów arystokratycznych czy ziemiańskich. Wyeksponowano również jej powiązania rodzinne i środowiskowe z krajami zachodnioeuropejskimi. Kandydatka do Europarlamentu przedstawiona została na tle jej aktywności publicznej w ruchu stowarzyszeniowym i politycznym, także, co wydaje się istotne dla jej ewentualnej przyszłej działalności na niwie Parlamentu Europejskiego - aktywności w organizacjach promujących jedność europejską (Fundacja Shumana). Treści artykułu dotyczyły wyeksponowania cech R. Thun wskazujących na jej wiedzę i umiejętności, także „predyspozycje” do pełnienia funkcji publicznych na niwie europejskiej, wynikające niejako m.in. z życiorysu, zaplecza rodzinnego i środowiskowego, wykształcenia, języków i doświadczeń wynikających ze znajomości stosunków europejskich. Opisy te złożyły się na przedstawienie sylwetki - wizerunku osoby profesjonalnie przygotowanej i niejako predestynowanej do pełnienia funkcji posła Parlamentu Europejskiego ${ }^{19}$.

W tygodnikach z 2014 r. szczególne miejsce poświęcono tematowi udziału w staraniach o fotel parlamentarzysty europejskiego kobiet prawicy Małgorzaty i Beaty Gosiewskich - wdów po Przemysławie Gosiewskim. Sylwetki przedstawione zostały z wyeksponowaniem znaczenia i działalności politycznej ich

\footnotetext{
7 J. Podgórska, Jak nie być sobą, „P” 2004, nr 5, 31 stycznia, s. 9.

18 Tamże, s. 8.

19 A. Rybak, Róża Europy, „P” 2004, nr 8, 21 lutego 2004, s. 32-34.
} 
męża, wicepremiera w rządzie Prawa i Sprawiedliwości. Posłanka Małgorzata Gosiewska, pierwsza żona posła oraz senatorka Beata Gosiewska - ich znaczenie oraz kariery polityczne, ukazane zostały w kontekście pewnego rodzaju „tła” w karierze ich męża. W prezentowaniu sylwetek niewiele miejsca zajęły kwestie dotyczące strony merytorycznej, dotyczącej ich przygotowania do pełnienia funkcji w Parlamencie Europejskim czy przebiegu ich indywidualnych karier politycznych. W odniesieniu do Małgorzaty wskazano jedynie na jej zaangażowanie polityczne w sprawy międzynarodowe, zwłaszcza w politykę wschodnią, działalność charytatywną, natomiast w opisach Beaty podkreślano, że głównie, w czasie przebiegu kariery Przemysława była „żoną przy mężu, wspierała go, pomagała, pracowała, ale o ogólnopolskiej polityce nie myślała”. Dopiero po tragicznej śmierci męża, jak podawał tygodnik - w 2011 r. Beata Gosiewska „przyszła do prezesa i powiedziała, że musi kandydować, bo jest żoną śp. Przemysława Gosiewskiego”. Natomiast Małgorzata, w przeciwieństwie do „poważniejszej, refleksyjnej, ale i zawziętej Beaty postrzegana była jako energiczna, lubi pożartować, bardzo otwarta, dusza towarzystwa”. To co je łączy, jak podawał jeden z polityków Prawa i Sprawiedliwości „to rodzaj celebryctwa politycznego. Obie wdowy zostały naszymi kandydatkami [Prawa i Sprawiedliwości - M.D.] nie ze względu na kompetencje, ale nazwisko" ${ }^{20}$. Kobiety polityki związane z Prawem i Sprawiedliwością ukazane zostały w rolach tzw. drugoplanowych, w pewnym zakresie pozostające $\mathrm{w}$ cieniu gremiów i osób decyzyjnych tej partii. Przedstawiony obraz kobiet, uczestniczek życia politycznego związanych z Prawem i Sprawiedliwością ukazał nieliczne przykłady kobiet „z rzeczywistym dorobkiem politycznym”, przykładowo przed 2011 r. Joanną Kluzik-Rostkowską czy Aleksandrą Natali-Świat. Eksponowano również w przekazie prasowym tematykę dotyczącą udziału kobiet w kampanii wyborczej tej partii - kobiet młodych, które „nie miały żadnej pozycji w partii, wywołane [niejako na potrzeby kampanii - M.D.] spośród wielu anonimowych działaczy". Według publicystów „Polityki” kobiety w Prawie i Sprawiedliwości nie odgrywały zbyt poważnej roli. Podkreślano, że na 38 szefów okręgów są tylko trzy kobiety. W komitecie politycznym - kierownictwie partii na 31 osób 28 to mężczyźni. Poza tym Prawo i Sprawiedliwość kieruje sześcioma komisjami w Sejmie żadna nie przypadła kobiecie. Także w dziewięcioosobowym sztabie wyborczym obecnej kampanii [do Europarlamentu - M.D.] zasiadali wyłącznie mężczyźni. $\mathrm{W}$ innych ugrupowaniach obraz udziału kobiet w politycznych gremiach decy-

20 J. Apelska, Trzy Gosiewskie w jednym PiS, „W” 2014, nr 5, 27 stycznia, s. 32-34; M. Dziedzic, Wdowy brukselskie, „P” 2014, nr 15, 9 kwietnia, s. 22-23. 
zyjnych nie pozostaje aż tak bardzo odmienny. Przykładowo - podaje cytowana „Polityka” - w Kancelarii Prezydenta Bronisława Komorowskiego - „wśród 18 doradców - etatowych i społecznych - jest jedna kobieta. Na 10 ministrów w Kancelarii też tylko jedna kobieta. W rządzie Donalda Tuska na 19 ministrów są trzy panie minister. W Platformie [Obywatelskiej] na 16 szefów regionów są dwie kobiety. Na 16 marszałków województw jest jedna kobieta. Na 106 prezydentów miast jest siedem kobiet. (...) w klubie poselskim Janusza Palikota kobiety stanowią niecałe 10\%. W 38 osobowym zarządzie lewicowego SLD jest zaledwie pięć kobiet"n1.

Kobietą, która odniosła niewątpliwy sukces w polskiej polityce pozostaje Elżbieta Bieńkowska, minister i wicepremier w rządzie Donalda Tuska. Nazywana przez media „generałem w spódnicy” czy „główną księgową Polski”. W nową rolę - jak mówią niektórzy - „głównej księgowej Polski weszła z godnością i łagodnym uśmiechem. Perfekcyjnie panuje nad emocjami, zwłaszcza publicznie, ponieważ z natury jest dość impulsywna i poza okiem kamer nie szczędzi mocnych słów współpracownikom i podwładnym”. Wizerunek Elżbiety Bieńkowskiej przedstawiony w prasie to obraz kobiety o silnym, bezkompromisowym charakterze, jednocześnie doskonale przygotowanej merytorycznie, kompetentnej w pełnionych funkcjach, konkretnej w podejmowanych decyzjach oraz zadbanej, młodej, o nienagannym wizerunku zewnętrznym, która zarządza sektorem unijnych pieniędzy w Polsce. Ma za zadanie stworzenie systemu, który przy pomocy funduszy unijnych przyczyni się do wzrostu konkurencyjności i innowacyjności polskiej gospodarki. „Jeśli jej się to uda - pisze publicystka , "Newsweek Polska», przejdzie do historii jako ważny polityk, który pchnął Polskę na drogę nowoczesności”22. Na pozytywne oceny mediów zasłużyła również Małgorzata Kidawa-Błońska, która „politykę ma w genach, jako prawnuczka czołowych polityków II RP: prezydenta Stanisława Wojciechowskiego i premiera Władysława Grabskiego. Sama zaczynała w Unii Wolności, z której przeszła do powstającej Platformy (...) działała w dwóch komisjach sejmowych - kultury i etyki poselskiej. Jest posłanką bardzo pilną - wzięła udział, jako jedna z nielicznych, w blisko w $100 \%$ sejmowych głosowań”. Małgorzata Kidawa-Błońska została powołana przez premiera w styczniu 2014 r., kiedy po listopadowej rekonstrukcji rządu w gabinecie zostały

21 W. Szacki, Panie pana, „P” 2014, nr 10, 5 marca, s. 22-23.

22 A. Pawlicka, Elżbieta, księgowa Polski, „NP” 2014, nr 15, 7 kwietnia, s. 72-75; A. Grzeszak, Brygada wicepremier Bieńkowskiej, „P” 2014, nr 10, 5 marca, s. 42- 44. 
tylko trzy panie minister i z powodów również wizerunkowych korzystniej było nominować posłankę niż posła. Kidawa-Błońska postrzegana jest również przez media, jako „otwarta na dziennikarzy, uśmiechnięta, sympatyczna, elegancka, mówiąca dobrą polszczyzną"23.

W odniesieniu do wyborów do Europarlamentu charakterystyce poddano sylwetkę Barbary Nowackiej, córki Izabeli Jarugi-Nowackiej, wicepremiera w rządzie Marka Belki. Kandydatkę lewicową, startującą z listy Ruchu Palikota okrzyknięto odkryciem eurokampanii i nadzieją w przyszłości lewicy. Jej dość czytelne lewicowe poglądy kształtowały się pod wpływem charyzmatycznej matki. Matkę przypomina również tym, że „przekonań broni umiejętnie i z dużą klasą, pod jej okiem [Izabeli Jarugi-Nowackiej - M.D.] zdobywała pierwsze polityczne doświadczenia, działała społecznie, angażowała się w ruch kobiet, protesty antywojenne. Przeszła przez młodzieżówkę Unii Pracy, potem przez samą Unię, której zresztą szefowała Izabela”, jej matka²4.

Pod względem analizy treści tekstów traktujących o Polkach zaangażowanych w działalność polityczną można podzielić niniejsze opracowania na dwie grupy. Z jednej strony artykuły ukazują oblicze kobiet o poważnym zapleczu politycznym, ugruntowanych poglądach politycznych oraz pozycji, popartej stabilnym miejscem w strukturach politycznych, w tym partyjnych, z drugiej zaś - obraz kobiet, które czynią próby „wejścia” w świat polityki przez drogę związaną z wcześniejszym doświadczeniem bliskich (męża, matki). Uzupełnieniem wizerunku kobiet polityki w Polsce może być obraz kobiet, które czynią próby „wejścia” do polityki dzięki wcześniejszej działalności publicznej pozapolitycznej, takiej jak sport, biznes, inne sfery związane np. z show biznesem. W wizerunku tych kobiet wskazuje się na znaczenie głównie tego, co związane jest z ich sławą i popularnością, tj. wcześniejsza kariera, rozpoznawalność ze względu na wcześniejsze zainteresowanie osobą ze strony mediów, cechy związane z wyglądem zewnętrznym. Jednoznacznie podkreślano aspekty związane z brakiem doświadczenia politycznego w ich aktywności publicznej, a nawet brakiem kompetencji merytorycznych do pełnienia obowiązków po uzyskaniu ewentualnego mandatu ${ }^{25}$.

23 W. Szacki, Nowa twarz Tuska, „P” 2014, nr 3, 15 stycznia, s. 22-23.

24 M. Dziedzic, Przyczajona lwica, „P” 2014, nr 25, 16 czerwca, s. 22-24.

25 Kobiety te określane są często w mediach „,elebrytkami politycznymi”. K. Nowicka, Pudelek Europejski, ,NP” 2014, nr 13, 24 marca, s. 28-31. 


\section{Uwagi podsumowujące}

Analizowane opracowania z tygodników „Polityka”, „Wprost” i „Newsweek Polska" ukazały obraz kobiet odnoszących sukcesy w sferze polityki. W ich wizerunku, zarówno dotyczy to kobiet krajów zachodnich (np. Hilary Clinton czy Angeli Merkel) jak i Polek wskazuje się głównie na sferę merytoryczną, w minimalnym stopniu skupiono się w tekstach na walorach wyglądu zewnętrznego kobiet. Po analizie publikacji prasowych można wywieźć, że mimo barier wskazywanych również $\mathrm{w}$ odniesieniu do uczestnictwa kobiet $\mathrm{w}$ polityce, nie do końca zasadne jest eksponowanie w dyskursie społecznym zagadnienia dotyczącego dyskryminacji kobiet pod względem ich udziału w sferze publicznej. Podane przykłady kobiet sukcesu politycznego wskazują wyraźnie na możliwości realizacji aktywności kobiet w różnych sferach, w tym stereotypowo jak polityka zarezerwowanych dla mężczyzn. Warto również podkreślić, że współczesny wizerunek kobiety polityka coraz rzadziej eksponowany jest w prasie przez pryzmat atrakcyjności fizycznej kobiet na rzecz wykształcenia, kompetencji, wiedzy, doświadczenia politycznego i zawodowego, profesjonalizmu ${ }^{26}$.

W odniesieniu do analizowanych treści gazet można stwierdzić, że tematyka dotycząca kobiet sfery polityki prezentowana była w specyficzny sposób, dominowały opisy sylwetek, głównie kobiet sukcesu ze świata polityki (opisywane postaci, biografie polityczne osobowości polityki), wystąpiły również informacje $\mathrm{w}$ formie komunikatu, reportażu lub wywiadu, przykładowo z kandydatkami do Europarlamentu lub postaciami wyróżniającymi się na tle innych kobiet polityki. Opisywane postaci cieszyły się zainteresowaniem mediów z tytułu przyjętego przez nie modelu życia nastawionego na karierę polityczną, wyraźnie eksponowanych „silnych”, wyrazistych cech osobowościowych. Artykuły prasowe traktujące o problematyce kobiet $\mathrm{w}$ polityce, poprzez opisy odnoszące się do konkretnych osób, przedstawiały problematykę w kontekście szerszym, chociażby praw kobiet, uwarunkowań dotyczących możliwości udziału i działalności kobiet $\mathrm{w}$ polityce, w tym występujących barier, przeszkód natury pozaprawnej czy stereotypów, a także, co wydaje się kwestią rzadko prezentowaną w opisach związanych z problematyką udziału kobiet w polityce - czynników sprzyjających czy ułatwiających kariery polityczne kobiet. Prezentowana tematyka odnosząca się do kobiet związana była często $\mathrm{z}$ aktualnie prowadzoną w przestrzeni spo-

26 Por. M. Posyłek, Nauczyciel, polityk, menadżer - studium wizerunku kobiety na polskim rynku politycznym, [w:] (Nie)obecność kobiet w przestrzeni publicznej, red. M. Pataj, Toruń 2014, s. 121-140. 
łecznej debatą publiczną, związaną chociażby z kampanią wyborczą w Polsce (do Europarlamentu) czy innych krajach świata (prezydencką w USA).

Opnie występujące na łamach tych gazet, odnoszące się do prezentowania wizerunku kobiet ze sfery polityki dotyczyły eksponowania sylwetek, z uwzględnieniem takich elementów jak kompetencje (strona merytoryczna), cechy osobowościowe, elementy składające się na przebieg i rozwój kariery politycznej, wygląd zewnętrzny. W prezentowaniu sylwetek rzadziej występowało eksponowanie cech, potwierdzających stereotypowe postrzeganie kobiety, jako tzw. słabej płci, delikatnej, szukającej oparcia w silnym mężczyźnie. Przeważały opisy raczej niwelujące stereotypy, funkcjonujące w szerokim dyskursie publicznym, podkreślające zaangażowanie kobiet w sferę zawodową, ich wiedzę i umiejętności, przygotowanie merytoryczne poparte wcześniejszą działalnością publiczną, doświadczenie polityczne predestynujące do sprawowania funkcji. Eksponowane były takie cechy osobowościowe, które ułatwiały niejako rozwijanie kariery politycznej.

Należy wskazać, że w 2004 r. tematyka kobiet polityki prezentowana była w bardzo niewielkim stopniu, co było warunkowane także znacznie mniejszym, w porównaniu do czasów obecnych, uczestnictwem kobiet w przestrzeni politycznej i co za tym idzie mniejszym zainteresowaniem mediów daną problematyką ${ }^{27}$. W porównaniu z 2004 r., tygodniki z 2014 r. w większej mierze $\mathrm{w}$ prezentowanych treściach wskazywały na konkretne informacje, akcentując stronę merytoryczną uczestniczek życia politycznego. W 2004 r. - w odniesieniu chociażby do prezentowanej w mediach Jolanty Kwaśniewskiej - główny akcent w opisach koncentrowano na jej zapleczu polityczno-środowiskowym, wyglądzie zewnętrznym, niejako w tle odnosząc się do jej przygotowania merytorycznego do pełnionych ówczesnych i ewentualnych przyszłych funkcji publicznych. W opisach kobiet polityki państw zachodnich, jak i Polek, wyraźnie pozytywne opinie prasowe i co się z tym wiąże, korzystniejszy wizerunek medialny prezentowano $\mathrm{w}$ odniesieniu do kobiet o wcześniejszym i szeroko zakrojonym doświadczeniu politycznym. W dominującej w tygodnikach tematyce krajowej, dotyczącej kobiet polityki, uwidaczniała się wyraźnie próba przeniesienia na grunt polski wizerunku medialnego amerykańskiego czy szerzej zachodniego.

Przedstawiony $\mathrm{w}$ tygodnikach obraz kobiet ze sfery polityki pozostaje pewnego rodzaju wyobrażeniem dotyczącym opisywanych postaci, także

27 Zob. również analizy dotyczące obecności problematyki kobiecej w gazetach codziennych. Kobiety zajmowały tam w 2005 r. około 13\% przestrzeni medialnej - Wizerunek kobiet i mężczyzn w mediach - analiza treści, Warszawa 2005 (Raport 17 w ramach projektu Phare). 
obrazem fragmentarycznym, zestawieniem informacji oraz oceną na temat danej osoby czy grupy osób (kobiet), uczestniczących w polityce i kreujących po części tzw. świat polityki. Na podstawie prezentowanego wizerunku kobiet $\mathrm{w}$ analizowanych tygodnikach można wskazać również na poparcie danego periodyku prasowego dla konkretnej opcji politycznej (przykładem tygodnik „Polityka” i dominujące pozytywne opinie na temat polityki Platformy Obywatelskiej i krytyczne na temat Prawa i Sprawiedliwości).

\section{ABSTRACT \\ The Image of Women in Sphere of Politics. Poland against a Background of Western Countries (based on the analysis of chosen weeklies)}

The study concerns the image of women in political spheres based on the material published in three opinion-forming Polish weeklies: Politics (Polityka), Straight (Wprost) and Newsweek Poland (Newsweek Polska). The participation of women in politics was analyzed in the weeklies from 2004 and 2014 in the context of the Polish elections to the European Parliament. The references to women involved in politics appeared in 10\% of the weekly issues in 2004 and in 35\% issues in 2014. The authors of the articles in 2004 concentrated on the presentation of the women's politicalsocial background and their physical appearance. Their competence to fulfill the public functions at that time and in the possible future was only mentioned. However, the weeklies in 2014 exposed the women's personalities more, emphasized their competence in politics, as well as the course and the development of their political careers. Conversely, their appearance was less focused on than 10 years before.

Key words: Polish weeklies, Polityka, Wprost, Newsweek Polska, European Parliament, Polish women and politics, the women in political spheres of western countries, a profile of the woman in the press, media and politics 


\section{PEЗЮME}

\section{Образ женщин в области политики. Польша на фоне западных стран (на основании анализа содержания избранных еженедельников)}

Анализ касается образа женщин в политике, который был проведен на основании содержания трех польских еженедельников «Политика», «Впрост» и «Ньюзвик Польша». Проблема участия женщин в политике анализировалась в еженедельниках с 2004 по 2014 гг. в контексте выборов в Польше в Европейский Парламент. Информация, касающаяся женщин в политике, составляла около $10 \%$ в 2004 г. и 35\% в 2014 г. в еженедельниках. В еженедельниках с 2004 г. авторы текстов концентрировали внимание на описании политического фона и политической среды описываемых женщин, их внешнем виде, далеко не в первую очередь, обращая внимание на их подготовленность к исполняемым функциям прежде и возможных будущих публичных функций. Тогда как в информации с 2014 года, касающейся женщин в политике, представлялись описания личностей из мира политики, акцентируя более четко, чем 10 лет назад, подготовку женщин, течение и развитие политической карьеры, в меньшей мере обращают внимание на внешний вид этих женщин.

Ключевые слова: Польские еженедельники: «Политика», «Впрост» и «Ньюзвик Польша», Европейский Парламент, польки и политика, женщины-политики западных стран, образ женщин-политиков в прессе, СМИ и политика 